\title{
NR3C1 Gene
}

National Cancer Institute

\section{Source}

National Cancer Institute. NR3C1 Gene. NCI Thesaurus. Code C28571.

This gene is involved in lig and-activated transcriptional regulation and mutations in the gene are associated with glucocorticoid resistance. 